\title{
Fauna Living in Colonies of Mussismilia hispida (Verrill) (Cnidaria: Scleractinia) in Four South-eastern Brazil Islands
}

\author{
João Miguel de Matos Nogueira \\ Departamento de Zoologia; Instituto de Biociências; Universidade de São Paulo; Rua do Matão, travessa 14, \\ n. 101; 05508-900; São Paulo - SP - Brazil
}

\begin{abstract}
Colonies of Mussismilia hispida were collected in four south-eastern Brazil islands and fixed in formalin. Volume, living and basal areas of each coral head were measured. Animals found over, under and inside the corals were sorted, resulting in 9657 specimens belonging to more than 130 taxa. The underside of the colonies was occupied by bivalves and colonial forms of sponges, bryozoans and ascidians. On the living surface, barnacles and cryptochiridean crabs were detected. The endolithic animals included polychaetes, bivalves and sipunculid worms. Most of the animals collected were vagile microcrustaceans. In general, the corals in this ecosystem: (1) act as a nursery place for the community; (2) provide protection for many species also found in other habitats; (3) support a community mainly omnivorous and detritivorous; (4) are initially colonised randomly.
\end{abstract}

Key words: Associated fauna, community ecology, corals, mussismilia hispida, South-eastern Brazil

\section{INTRODUCTION}

Scleractinian corals are well known by their capacity of building large carbonate structures which are colonised by a great variety of animals. These, are attached to the coral bases, bore the skeleton, or live over or under the colonies (McCloskey, 1970; Young, 1986; Arvanitides and Koukouras, 1994). Many authors have emphasised the destructive impact of the endolithic fauna on coral colonies, a process known as bioerosion (Hein and Risk, 1975; MacGeachy and Stearn, 1976; Hutchings, 1986; Kiene and Hutchings,1992); among the studies with a more specific focus, those on sponges (Rützler, 1975), molluscs (Hadfield, 1976; Morton, 1983; Moretzsohn and Tsuchyia, 1992), polychaetes (Kohn and Lloyd, 1973; Arvanitides and Koukouras, 1994; Nogueira, 2000), and sipunculids (Rice, 1976; Rice and Macintyre, 1982) should be noted.
The best known of the vagile animals that live over or under the coral heads are decapods, reported by Patton (1966) and Coles (1980), among several other studies. Other groups, particularly microcrustaceans, were only treated in papers that investigated all the animals associated with the corals, such as those by McCloskey (1970) and Tsuchyia et al. (1989).

In Brazil, the only study that dealt with coralsassociated fauna has been carried out by Young (1986) on the northeastern coast (State of Paraíba). However, other studies on associated communities have been conducted, such as those on sponges (Duarte and Nalesso, 1996), bryozoans (Morgado, 1980), polychaete tubes (Nalesso et al. 1995), and algal fields (Montouchet, 1979; Tanaka, 2000), all of these on the coast of the state of São Paulo, south-eastern Brazil. The aim of the present study was to describe the fauna associated with the coral Mussismilia hispida in four islands off the northern coast of the State of São Paulo, and to 
investigate the patterns which determined the structure of these communities.

\section{MATERIAL AND METHODS}

Twenty-four coral heads of Mussismilia hispida, a massive coral endemic to the Brazilian coast, were dislodged from the original substrate with a chisel, wrapped in plastic bags and collected in four islands off the coast of the State of São Paulo; islands were preferred because corals are very rare on mainland shore, due to human impact. After a few hours, the corals were fixed in $4 \%$ formalin solution. All samples were collected in the morning, in protected areas, from 4 to $8 \mathrm{~m}$ deep. Five coral heads were collected at Búzios Island (23o 48'S 45o 08'W), ten at Vitória Island (23o45'S 45o 00'), five at Mar Virado Island (23o $35^{\prime} \mathrm{S} 45010^{\prime} \mathrm{W}$ ) and four at Palmas Island (23o30'S 45o 00'W), in 30 June 1992, 10 January 1993, 14 October 1993, and 4 December 1993, respectively.

In the laboratory, the metric parameters of each coral head were measured. Subsequently, the fixative (4\% formalin plus seawater) was examined under dissection microscope to sort all the animals observed, independent of size. Finally, the corals were broken into pieces by hammer and chisel, in order to obtain the endolithic fauna. Most of the specimens collected were identified, or sent to specialists for identification, and subsequently counted. Polychaetes, the most prolific of the endolithic animals, were so fragile that they were almost completely destroyed by the breakage of the corals; therefore it was impossible to conduct an appropriate study of this group and it has not been considered for the subsequent analysis.

The community descriptors used to explain species distribution in the 24 coral heads were Shannon's Diversity Index $H^{\prime}$ (coded as $\mathrm{H}$ ), Pielou's Evenness Index $J^{\prime}(\mathrm{J})$, and species richness $(\mathrm{S})$; the metric parameters considered for each colony were: volume $(\mathrm{V})$, basal area (B) and living surface (L). Community descriptors (indexes H, J and $\mathrm{S}$ ) were calculated by standard formulas (Magurran, 1988). Cluster analysis was done by the method Morisita-Horn, as proposed by Magurran (1988), since it considers both qualitative and quantitative aspects (Magurran, 1988).

\section{RESULTS}

A total of 9657 individuals belonging to at least 130 species was obtained in the 24 coral heads, besides colonial species. In all stations (each of the four islands), the most representative groups were copepods, isopods and amphipods (Table 3).

The analysis of the fauna living in M. hispida colonies was divided in four groups: (1) animals attached to the bases of the corals; (2) endolothic animals, which bored the coral skeletons or occupied empty crevices and cavities, but hardly, or never, leave the corals; (3) animals on the living surface of the corals; and (4) vagile animals, collected in the fixative, here considered those which crawled over or under the colonies, as well as those living over the corals or inside their cavities but able to leave them. For practical reasons, tables 1-3 list only the station (each of the four islands) where the species were found, not the corals individually.

\section{Animals attached to the bases (Table 1)}

Among the incrusting animals attached to the bases of the corals, bryozoans were the most frequent, found in 23 coral heads, followed by sponges (20 coral heads), hydrozoans (14) and ascidians (9). Bryozoans occupied the inner parts of the bases of the corals, while sponges and ascidians were observed only at their peripheries. Several times, it was possible to recognise sponges and ascidians growing over dead bryozoans, which had probably been killed by them. Sponges and bryozoans were not identified on this study, but the ascideans were mainly didemnideans. Besides the colonial forms, solitary anemones, all very small and young, and several species of bivalves were collected.

\section{Endolithic animals (Table 1)}

As mentioned above, only a limited number of polychaetes were in good condition and for this reason the whole group was dropped out from the present study. Bivalves were not very common inside the corals collected, as the famous boring clam Lithophaga bisulcata (Orbigny) (Fig. 2A) appeared in half of the sampled corals, and the two other species observed were even less frequent and represented by fewer specimens. Sipunculids were even rarer, only eight individuals, belonging to three species were seen. 
Table 1 - Number of specimens (right), and of coral colonies (left) in which they were present, at each station. In case of colonial animals, the only number means the number of corals in which they were found.

\begin{tabular}{|c|c|c|c|c|c|}
\hline \multirow{2}{*}{ Animals Observed } & \multicolumn{4}{|c|}{ Islands } & \multirow{2}{*}{ Total } \\
\hline & Búzios & Vitória & Mar Virado & Palmas & \\
\hline \multicolumn{6}{|l|}{ ATTACHED TO THE BASES } \\
\hline Porifera & 3 & 10 & 4 & 3 & 20 \\
\hline Hydrozoa & 3 & 3 & 5 & 3 & 14 \\
\hline \multicolumn{6}{|l|}{ Anthozoa } \\
\hline Aiptasia pallida & - & $1 ; 1$ & $12 ; 3$ & - & $13 ; 4$ \\
\hline Morph. 1 & - & $4 ; 25$ & - & - & $4 ; 25$ \\
\hline Morph. 2 & $2 ; 9$ & $1 ; 5$ & - & $1 ; 2$ & $4 ; 16$ \\
\hline Morph. 3 & $1 ; 1$ & - & - & $1 ; 1$ & $2 ; 2$ \\
\hline Morph. 4 & - & - & $1 ; 1$ & - & $1 ; 1$ \\
\hline Morph. 5 & - & $1 ; 2$ & - & - & $1 ; 2$ \\
\hline Morph. 6 & $1 ; 1$ & - & - & - & $1 ; 1$ \\
\hline Morph. 7 & - & - & - & $1 ; 1$ & $1 ; 1$ \\
\hline \multicolumn{6}{|l|}{ Bivalvia } \\
\hline Barbatia candida & - & $2 ; 3$ & $1 ; 1$ & $1 ; 1$ & $4 ; 5$ \\
\hline Chama congregata & - & $6 ; 13$ & $3 ; 6$ & $3 ; 7$ & $12 ; 26$ \\
\hline Corbula sp. & - & - & - & $1 ; 2$ & $1 ; 2$ \\
\hline Crassostrea rhizophorae & - & $1 ; 1$ & - & - & $1 ; 1$ \\
\hline Gastrochaena hians & - & $1 ; 1$ & - & - & $1 ; 1$ \\
\hline Hiatella solida & - & $3 ; 6$ & $3 ; 5$ & $1 ; 1$ & $7 ; 12$ \\
\hline Isognomon sp. & - & - & $1 ; 1$ & - & $1 ; 1$ \\
\hline Leptopecten bavayi & - & $1 ; 1$ & - & - & $1 ; 1$ \\
\hline Modiolus carvalhoi & $1 ; 1$ & $2 ; 2$ & $2 ; 2$ & $2 ; 2$ & $7 ; 7$ \\
\hline Musculus lateralis & - & - & $1 ; 1$ & - & $1 ; 1$ \\
\hline Pseudochama radians & - & $1 ; 1$ & - & - & $1 ; 1$ \\
\hline Sphenia antilensis & - & - & $1 ; 4$ & $1 ; 1$ & $2 ; 5$ \\
\hline Bryozoa & 4 & 10 & 5 & 4 & 23 \\
\hline Urochordata & 1 & 4 & 3 & 1 & 9 \\
\hline \multicolumn{6}{|l|}{ ENDOLITHIC } \\
\hline \multicolumn{6}{|l|}{ Bivalvia } \\
\hline Arca imbricata & - & $3 ; 3$ & $2 ; 5$ & $2 ; 2$ & $7 ; 10$ \\
\hline Lithophaga bisulcata & - & $6 ; 24$ & $2 ; 4$ & $4 ; 15$ & $12 ; 43$ \\
\hline Petricola typica & - & $4 ; 9$ & $4 ; 10$ & $3 ; 8$ & $11 ; 27$ \\
\hline \multicolumn{6}{|l|}{ Sipuncula } \\
\hline Aspidosiphon elegans & - & - & $1 ; 1$ & - & $1 ; 1$ \\
\hline Phascolosoma stephensoni & - & $2 ; 2$ & $1 ; 1$ & - & $3 ; 3$ \\
\hline Themiste alutacea & - & - & $2 ; 4$ & - & $2 ; 4$ \\
\hline \multicolumn{6}{|l|}{ ON THE LIVING SURFACE } \\
\hline \multicolumn{6}{|l|}{ Cirripedia } \\
\hline Ceratoconcha floridana & $2 ; 23$ & $10 ; 64$ & $5 ; 24$ & $2 ; 15$ & $19 ; 126$ \\
\hline \multicolumn{6}{|l|}{ Decapoda } \\
\hline Troglocarcinus corallicola & $3 ; 3$ & $1 ; 1$ & - & - & $4 ; 4$ \\
\hline Opecarcinus hypostegus & $2 ; 3$ & $1 ; 2$ & - & - & $3 ; 5$ \\
\hline \multicolumn{6}{|l|}{ Teleostei } \\
\hline Chriolepis vespa & - & $1 ; 1$ & - & - & $1 ; 1$ \\
\hline Emblemariopsis signifera & $3 ; 4$ & - & $1 ; 1$ & - & $4 ; 5$ \\
\hline
\end{tabular}


Table 2 - Numbers of vagile individuals (right) of gastropods, polyplacophors, ophiuroids, and echinoids, and of corals (left) in which they were present, at each station.

\begin{tabular}{|c|c|c|c|c|c|}
\hline \multirow{2}{*}{ Animals Observed } & \multicolumn{4}{|c|}{ Islands } & \multirow{2}{*}{ Total } \\
\hline & Búzios & Vitória & Mar Virado & Palmas & \\
\hline \multicolumn{6}{|l|}{ Gastropoda } \\
\hline Acmaea sp. & - & - & - & $1 ; 1$ & $1 ; 1$ \\
\hline Alvania auberiana & - & $1 ; 1$ & - & - & $1 ; 1$ \\
\hline Alvania sp. & - & $2 ; 3$ & $2 ; 2$ & $1 ; 1$ & $5 ; 6$ \\
\hline Amonicera sp. & $1 ; 1$ & $2 ; 2$ & $2 ; 9$ & - & $5 ; 12$ \\
\hline Amphitalamus sp. & - & $1 ; 14$ & - & - & $1 ; 14$ \\
\hline Astraea olfersii & $1 ; 1$ & $1 ; 1$ & - & - & $2 ; 2$ \\
\hline Balcis breviuscula & $1 ; 1$ & - & - & - & $1 ; 1$ \\
\hline Bittium varium & $1 ; 1$ & $1 ; 1$ & $5 ; 15$ & $1 ; 1$ & $8 ; 18$ \\
\hline Caecum sp. & - & - & $1 ; 4$ & - & $1 ; 4$ \\
\hline Calliostoma sp. & - & - & - & $1 ; 3$ & $1 ; 3$ \\
\hline Cantharus auritulus & - & $1 ; 2$ & - & - & $1 ; 2$ \\
\hline Cerithiopsis gemmulosa & - & $2 ; 2$ & $2 ; 3$ & - & $4 ; 5$ \\
\hline Collisella subrugosa & - & $1 ; 1$ & - & - & $1 ; 1$ \\
\hline Crepidula sp. & $1 ; 2$ & $1 ; 2$ & - & - & $2 ; 4$ \\
\hline Emarginella sp. & $1 ; 1$ & - & - & - & $1 ; 1$ \\
\hline Engina turbinella & $1 ; 1$ & - & - & $1 ; 1$ & $2 ; 2$ \\
\hline Finella dubia & - & - & $1 ; 1$ & - & $1 ; 1$ \\
\hline Fissurella clenchi & - & - & - & $1 ; 1$ & $1 ; 1$ \\
\hline Morula nodulosa & - & $2 ; 2$ & - & $1 ; 1$ & $3 ; 3$ \\
\hline Odostomia bissuturalis & - & - & - & $1 ; 1$ & $1 ; 1$ \\
\hline Odostomia dux & - & - & $1 ; 2$ & - & $1 ; 2$ \\
\hline Odostomia impressa & - & $1 ; 1$ & - & - & $1 ; 1$ \\
\hline Odostomia sp. & - & $1 ; 1$ & $1 ; 3$ & - & $2 ; 4$ \\
\hline Rissoella ornata & $1 ; 1$ & $7 ; 188$ & $3 ; 5$ & $1 ; 1$ & $12 ; 195$ \\
\hline Rissoina bryerea & - & - & $1 ; 1$ & - & $1 ; 1$ \\
\hline Scissurella sp. & $2 ; 2$ & $1 ; 2$ & - & - & $3 ; 4$ \\
\hline Tricolia affinis & - & - & $2 ; 2$ & - & $2 ; 2$ \\
\hline Turbonilla sp. & - & - & $1 ; 1$ & - & $1 ; 1$ \\
\hline Unidentified Vitrinellidae & $1 ; 3$ & $1 ; 1$ & $2 ; 8$ & $1 ; 4$ & $5 ; 16$ \\
\hline \multicolumn{6}{|l|}{ Polyplacophora } \\
\hline Callistochiton sp. & - & $1 ; 1$ & - & - & $1 ; 1$ \\
\hline Ischnochiton sp. & - & - & - & $1 ; 1$ & $1 ; 1$ \\
\hline \multicolumn{6}{|l|}{ Ophiuroidea } \\
\hline Ophiactis savignyi & $4 ; 14$ & $5 ; 22$ & $4 ; 63$ & $3 ; 7$ & $16 ; 106$ \\
\hline \multicolumn{6}{|l|}{ Echinoidea } \\
\hline Arbacia lixula & $1 ; 2$ & - & - & - & $1 ; 2$ \\
\hline Echinometra lucunter & $1 ; 1$ & $3 ; 4$ & $1 ; 1$ & $2 ; 2$ & $7 ; 8$ \\
\hline Lytechinus variegatus & - & $2 ; 2$ & - & - & $2 ; 2$ \\
\hline
\end{tabular}

Animals on the living surface (Table 1)

Only few individuals were able to install themselves on the living surface of the corals because of the there occurring nematocysts (Highsmith, 1980). Throughout the present study, few species were found in close contact with the living tissues of the host, one barnacle and two gal crabs (Fig. 2B, C). Not in close contact, but in holes in the living surface, two species of fishes were found. 
Table 3 - Numbers of vagile individuals (right) of ostracods, copepods, isopods, amphipods, tanaidaceans, pantopods, and decapods, and of corals (left) in which they were present, at each station.

\begin{tabular}{|c|c|c|c|c|c|}
\hline \multirow{2}{*}{ Animals Observed } & \multicolumn{4}{|c|}{ Islands } & \multirow{2}{*}{ Total } \\
\hline & Búzios & Vitória & Mar Virado & Palmas & \\
\hline Ostracoda & $4 ; 21$ & $9 ; 432$ & $5 ; 61$ & $4 ; 70$ & $22 ; 584$ \\
\hline \multicolumn{6}{|l|}{ Copepoda } \\
\hline Calanoida & $1 ; 1$ & $3 ; 15$ & - & $3 ; 9$ & $7 ; 25$ \\
\hline Harpacticoida & $4 ; 32$ & $10 ; 3003$ & $4 ; 443$ & $4 ; 936$ & $22 ; 4414$ \\
\hline Siphonostomatoida & $4 ; 9$ & $9 ; 108$ & $5 ; 141$ & $4 ; 73$ & $22 ; 331$ \\
\hline Other Copepods & $3 ; 6$ & $8 ; 200$ & $4 ; 33$ & $4 ; 39$ & $19 ; 278$ \\
\hline \multicolumn{6}{|l|}{ Isopoda } \\
\hline Bagatus minutus & $3 ; 27$ & $8 ; 749$ & $3 ; 32$ & $4 ; 41$ & $18 ; 849$ \\
\hline Bagatus nereus & $3 ; 51$ & $2 ; 18$ & - & $2 ; 8$ & $7 ; 77$ \\
\hline Excirollana armata & - & $3 ; 8$ & $2 ; 3$ & - & $5 ; 11$ \\
\hline Jaeropsis dubia & $2 ; 3$ & $7 ; 27$ & $5 ; 27$ & $4 ; 49$ & $18 ; 106$ \\
\hline Santias milleri & - & - & $2 ; 14$ & $3 ; 28$ & $5 ; 42$ \\
\hline Stenetrium sp.1 & $1 ; 1$ & $3 ; 38$ & $4 ; 21$ & $4 ; 50$ & $12 ; 110$ \\
\hline Stenetrium sp.2 & $1 ; 5$ & $6 ; 34$ & $4 ; 21$ & $4 ; 39$ & $15 ; 99$ \\
\hline Unidentified Janiridae & $1 ; 4$ & $4 ; 115$ & - & $3 ; 39$ & $8 ; 158$ \\
\hline Unidentified Asellota & - & $6 ; 27$ & $2 ; 5$ & $1 ; 1$ & $9 ; 33$ \\
\hline \multicolumn{6}{|l|}{ Amphipoda } \\
\hline Amphilochus neapolitanus & $2 ; 5$ & $5 ; 25$ & $5 ; 39$ & $3 ; 12$ & $15 ; 81$ \\
\hline Ampithoe ramondi & $1 ; 4$ & $4 ; 20$ & $1 ; 1$ & $1 ; 1$ & $7 ; 26$ \\
\hline Caprella scaura & - & $4 ; 20$ & $2 ; 15$ & - & $6 ; 35$ \\
\hline Elasmopus brasiliensis & $1 ; 3$ & $2 ; 18$ & $1 ; 4$ & - & $4 ; 25$ \\
\hline Elasmopus pectinicrus & - & $4 ; 132$ & - & - & $4 ; 132$ \\
\hline Elasmopus rapax & $3 ; 7$ & $2 ; 110$ & $3 ; 7$ & $3 ; 13$ & $11 ; 137$ \\
\hline Unidentified Elasmopus & - & $1 ; 16$ & - & - & $1 ; 16$ \\
\hline Erichtonius brasiliensis & $4 ; 11$ & $6 ; 44$ & - & - & $10 ; 55$ \\
\hline Gammaropsis togoensis & $4 ; 104$ & $2 ; 143$ & $3 ; 10$ & $4 ; 13$ & $13 ; 270$ \\
\hline Grandidierella bonnieroides & - & $1 ; 3$ & - & - & $1 ; 3$ \\
\hline Jassa sp. & - & $1 ; 1$ & - & - & $1 ; 1$ \\
\hline Maera inaequipes & - & $9 ; 41$ & $1 ; 2$ & $4 ; 16$ & $14 ; 59$ \\
\hline Maera grossimana & $3 ; 9$ & $6 ; 36$ & $2 ; 2$ & $3 ; 4$ & $14 ; 51$ \\
\hline Maera quadrimana & $2 ; 2$ & $4 ; 10$ & - & $1 ; 1$ & $7 ; 13$ \\
\hline Unidentified Maera & - & $1 ; 14$ & - & - & $1 ; 14$ \\
\hline Leucothoe denticulata & $3 ; 36$ & $5 ; 15$ & $4 ; 13$ & $3 ; 25$ & $15 ; 89$ \\
\hline Stenothoe valida & $3 ; 5$ & $1 ; 2$ & $2 ; 3$ & - & $6 ; 10$ \\
\hline Unidentified Caprellidae & - & $4 ; 32$ & $5 ; 199$ & $3 ; 6$ & $12 ; 237$ \\
\hline Unidentified Gammaridae & - & $1 ; 14$ & - & - & $1 ; 14$ \\
\hline \multicolumn{6}{|l|}{ Tanaidacea } \\
\hline Leptochelia savignyi & $3 ; 8$ & $8 ; 107$ & $1 ; 6$ & $2 ; 2$ & $14 ; 123$ \\
\hline Zeuxo coralensis & - & - & - & $1 ; 1$ & $1 ; 1$ \\
\hline Apseudidae & $4 ; 20$ & $8 ; 239$ & $2 ; 2$ & $3 ; 21$ & $17 ; 282$ \\
\hline \multicolumn{6}{|l|}{ Pantopoda } \\
\hline Achelia sawayai & $1 ; 1$ & $2 ; 2$ & - & - & $3 ; 3$ \\
\hline Anoplodactylus petiolatus & - & $3 ; 4$ & - & - & $3 ; 4$ \\
\hline Tanystylum isabellae & - & $1 ; 1$ & $1 ; 2$ & - & $2 ; 3$ \\
\hline \multicolumn{6}{|l|}{ Decapoda } \\
\hline Mithrax (Mithraculus) forceps & - & $3 ; 3$ & - & $2 ; 2$ & $5 ; 5$ \\
\hline Mithrax (Mithrax) hispidus & - & - & - & $1 ; 1$ & $1 ; 1$ \\
\hline Mithrax (Mithrax) tortugae & - & $1 ; 1$ & - & - & $1 ; 1$ \\
\hline Pachycheles monilifer & $2 ; 5$ & - & $2 ; 3$ & $2 ; 2$ & $6 ; 10$ \\
\hline Pelia rotunda & $1 ; 1$ & $1 ; 1$ & - & - & $2 ; 2$ \\
\hline Periclimenaeus sp.1 & - & - & $1 ; 2$ & - & $1 ; 2$ \\
\hline Periclimenaeus sp.2 & - & - & $1 ; 4$ & - & $1 ; 4$ \\
\hline Synalpheus longicarpus & $2 ; 2$ & $2 ; 2$ & $2 ; 2$ & $2 ; 6$ & $8 ; 12$ \\
\hline Synalpheus sanctitomae & $1 ; 1$ & - & - & - & $1 ; 1$ \\
\hline
\end{tabular}


Vagile animals (Tables 2 and 3)

More than $50 \%$ of all the animals collected were copepods, but, due to the lack of experts, they were identified only until the order level, and, eventhough, Poecilostomatoida and Cyclopoida were here considered as "Other Copepods". Cyclopoids were not numerous, however five new species of this group were detected. Somewhat less prolific were ostracods, amphipods, isopods, and tanaids. Among tanaids, it was very common an undescribed species of Apseudidae, a family that had only once been reported in Brazil at the time of identification (Matsunaro, personal communication). Decapods were much scarcer than the other crustaceans, although two species of shrimps, belonging to the genus Periclimenaeus and new to science at the time of identification, were discerned.

Gastropods were also numerous, and a great amount of species was identified in the present study, most of them, however, with few individuals and few occurrences on the corals; Rissoella ornata Simone, described from this material (Simone, 1995), occurred in half of the sampled corals, in great densities in some colonies (Table 3); besides R. ornata, species of two other new species of gastropods, belonging to the genera Ammonicera and Amphitalamus, were collected.

The number of bivalves in the fixative was, as expected, very low and the specimens detected were probably in the sediment below the corals. Two groups of echinoderms were observed: one species of ophiuroid and three of echinoids; ophiuroids were very common, found in 16 corals, while echinoids were rare.

\section{Statistical analysis}

The values of the community descriptors and the metric parameters for each colony of the community are listed in Table 4; t-tests relating each of the metric parameters with each of the community descriptors were performed, but no significant correlation was observed in any of them. Morisita-Horn cluster analysis also showed great heterogeneity among the corals studied, since one third of the colonies have percentage of similarity below $50 \%$ (Fig. 1).

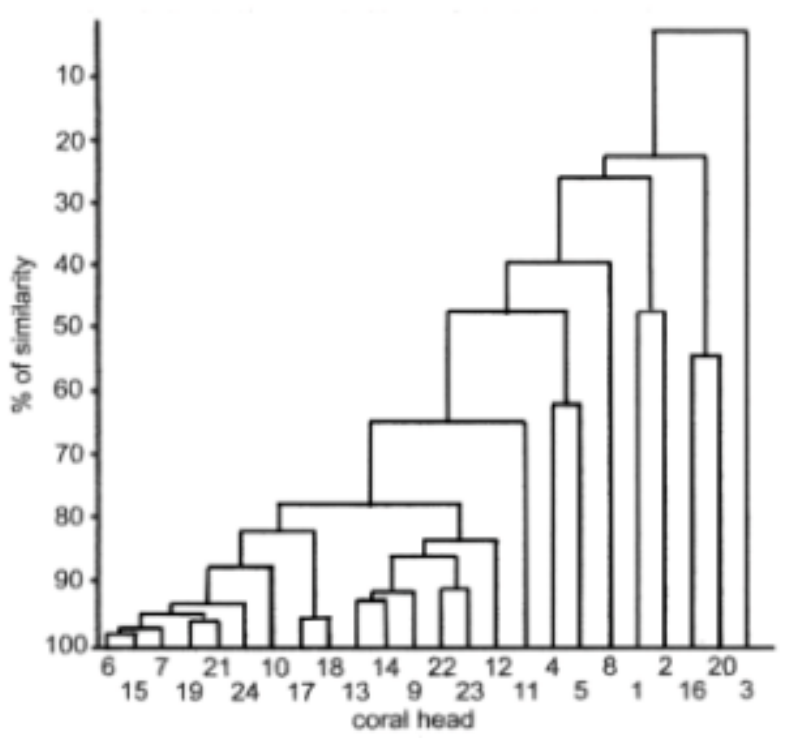

Figure 1 - Cluster analysis of the coral heads, following Morisita-Horn method, modified by Magurran (1988).

Table 4 - Attributes of the 24 colonies of Mussismilia hispida studied. Diversity indexes (H, J, S) based on the fauna present in each coral head.

\begin{tabular}{ccccccccccccccccccccccccc}
\hline Colony & $\mathbf{1}$ & $\mathbf{2}$ & $\mathbf{3}$ & $\mathbf{4}$ & $\mathbf{5}$ & $\mathbf{6}$ & $\mathbf{7}$ & $\mathbf{8}$ & $\mathbf{9}$ & $\mathbf{1 0}$ & $\mathbf{1 1}$ & $\mathbf{1 2}$ & $\mathbf{1 3}$ & $\mathbf{1 4}$ & $\mathbf{1 5}$ & $\mathbf{1 6}$ & $\mathbf{1 7}$ & $\mathbf{1 8}$ & $\mathbf{1 9}$ & $\mathbf{2 0}$ & $\mathbf{2 1}$ & $\mathbf{2 2}$ & $\mathbf{2 3}$ & $\mathbf{2 4}$ \\
\hline $\mathrm{H}$ & 2.22 & 2.39 & 1.36 & 2.71 & 2.91 & 1.95 & 1.95 & 2.38 & 2.4 & 1.92 & 2.61 & 2.51 & 1.87 & 2.25 & 1.93 & 2.53 & 2.6 & 2.24 & 1.85 & 2.3 & 2.06 & 2.38 & 2.55 & 1.41 \\
$\mathrm{~J}$ & 0.41 & 0.56 & 0.49 & 0.62 & 0.65 & 0.35 & 0.36 & 0.66 & 0.36 & 0.34 & 0.58 & 0.64 & 0.27 & 0.38 & 0.24 & 0.48 & 0.43 & 0.38 & 0.33 & 0.53 & 0.34 & 0.57 & 0.44 & 0.21 \\
$\mathrm{~S}$ & 26 & 18 & 6 & 23 & 27 & 26 & 23 & 15 & 38 & 24 & 22 & 20 & 32 & 31 & 51 & 26 & 43 & 32 & 28 & 16 & 35 & 23 & 31 & 38 \\
$\mathrm{~V}(\mathrm{ml})$ & 500 & 100 & 250 & 400 & 100 & 400 & 400 & 350 & 450 & 400 & 300 & 300 & 650 & 400 & 550 & 160 & 500 & 280 & 280 & 460 & 800 & 170 & 350 & 320 \\
$\mathrm{~B}\left(\mathrm{~cm}^{2}\right)$ & 280 & 40 & 120 & 252 & 57 & 217 & 205 & 147 & 420 & 245 & 143 & 160 & 380 & 180 & 295 & 65 & 307 & 127 & 114 & 212 & 431 & 85 & 187 & 153 \\
$\left(\mathrm{~cm}^{2}\right)$ & 470 & 95 & 280 & 430 & 98 & 413 & 435 & 313 & 480 & 380 & 275 & 280 & 625 & 350 & 580 & 142 & 485 & 273 & 298 & 460 & 776 & 170 & 373 & 342 \\
\hline
\end{tabular}

\section{DISCUSSION}

Choi (1984) studied the ecological succession among reef cavity-dwellers in coral rubble and observed that the bryozoans were among the first colonisers of hard substrates, but were later killed and recovered by sponges and ascidians. Further, Jackson and Winston (1982) verified that sponges and ascidians need stronger circulation of water than bryozoans. This agrees well with the patterns observed on the corals analysed for the present study, on which bryozoans were detected alive 
only at the inner bases, where circulation is poor, while in areas with stronger circulation, such as the periphery of the colonies, bryozoans had been overgrown by other forms. All these animals contribute for the corals by covering the exposed areas of the calcareous bases and preying upon the larvae of boring species (Buss and Jackson, 1979; Kiene and Hutchings, 1992), protecting the host in both cases.

Polychaetes are always very numerous on associated communities, and many species are adapted to symbiotic habits (Martim and Britayev, 1998). In the present study, as stated before, polychaetes were not treated, but there are several references in the literature to coral-associated polychaetes, such as Kohn and Lloyd (1973), in the Indian Ocean, McCloskey (1970) and Arvinitides and Koukouras (1994), in northern Atlantic and Mediterranean, respectively. The ability of these animals to bore calcareous substrates is also well known (Hutchings, 1986; Chughtai and Knight-Jones, 1988).

In a recent study, Nogueira (2000) analysed the polychaetes living in colonies of $M$. hispida in the same area as the present work and reported that these animals, especially members of the families Syllidae, Spionidae, Serpulidae, and Eunicidae, in this order, were very abundant. As a result of that study, several new taxa (genera and species) are currently being described (Nogueira and Amaral, 2000, 2001; Nogueira and ten Hove, 2000; Nogueira and Rizzo, 2001; Nogueira et al., 2001 a and b; Nogueira, 2002; Nogueira and KnightJones, 2002; Nogueira and San Martín, 2002; Steiner et al., 2002).

According to Fauchald and Jumars (1979), the feeding guilds of the most representative families of polychaetes in the present study observed suggested that they were very important on these communities, controlling populations of microcrustaceans, feeding on suspended materials, and on detritus and bacteria entrapped in coral mucus.

Other well known group of endolithic animals is that of bivalves, whose importance should be seen in terms of making great holes at the corals bases, causing their dislodgement from the substrate (MacGeachy and Stearn, 1976; Hutchings, 1986), rather then in the number of specimens; another role of them is increasing the available space for larval settlement of other borers (McCloskey, 1970). The most studied group of boring bivalves is the subfamily Lithophaginae (family Mytilidae), in which this habitat has evolved from earlier forms attached to the substrate (Yonge, 1955). Lithophaga has been found world-wide (Hein and Risk, 1975; MacGeachy and Stearn, 1976; Moretzsohn and Tsuchyia, 1992; Young, 1986), boring corals by means of acid secretions and rotating movements of the valves (Yonge, 1955). In the present study, L. bisulcata was the only lithophaginean observed (Fig. 2A) and it appeared only in half of the sampled corals; although its occurrence was limited, it represents the most numerous and most frequent species of bivalves. Lithophaga bisulcata was much more common in the dead areas of the coral colonies, but in two of them the openings of the holes were in the living surface of the corals; it is impossible to precise whether these individuals bored living corals or dead areas which were later recovered by the hosts. Young (1986), on the northeastern coast of Brazil, observed that L. bisulcata is able to bore the living surface of the corals, but does it only when no dead areas are available.

Another bivalve commonly found drilling into $M$. hispida is $P$. typica, whose boring activity is only by mechanical means (Morton, 1983). An interesting observation occurred in regard to the third species, A. imbricata. This animal is known as a bissed bivalve that attaches itself to preexisting holes and cavities of corals and calcareous substrates. Rios (1985) reported that this species was able to bore the calcareous material only superficially, to accommodate the valves as the animal grows (see also Morton, 1983), not making profound holes. However, during the present study, large specimens have fitted themselves deeply into the corals, making cavities with large openings and internal surface coinciding exactly with the shape of the valves; this led to the conclusion that this species is actually able to bore deeper into the substrate than previously claimed, although its boring mechanism seems to be rougher than those of the other boring bivalves. 


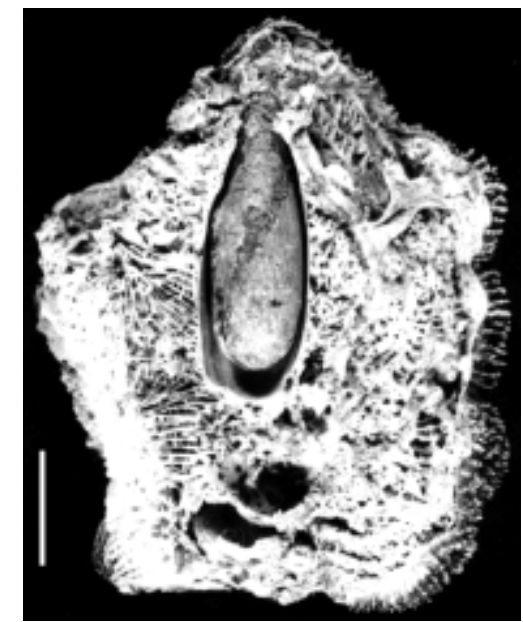

A

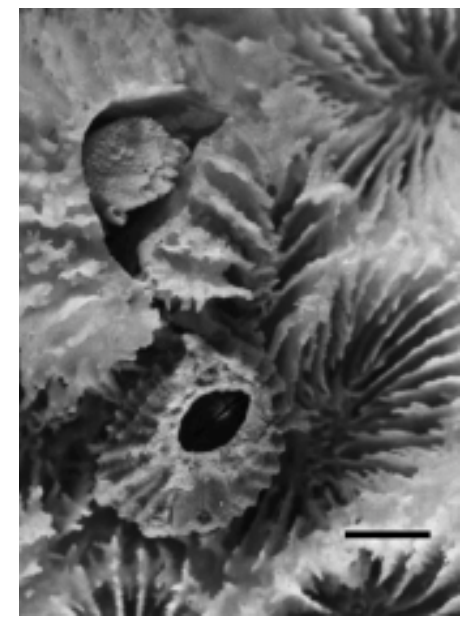

B

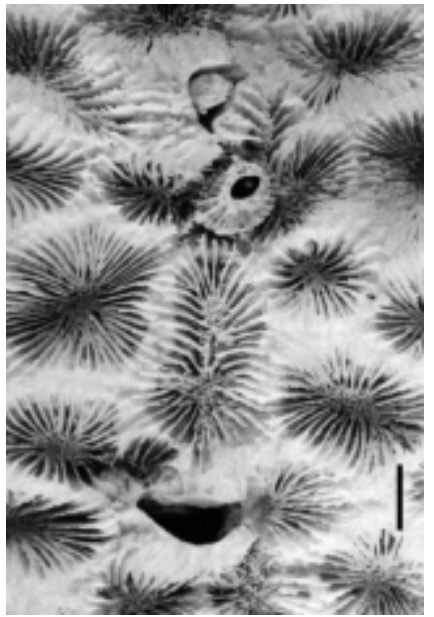

C

Figure 2 - A. Cross section of a coral head, showing Lithophaga bisulcata inside its burrow; B. Living surface of a coral head (coral tissues removed), with one hole Ceratoconcha floridana and two of Opecarcinus hypostegus, the superior one with the crab inside; C. Detail of figure B, showing one gall-crab (above) and one barnacle (below). Scale bars: A. $15 \mathrm{~mm}$; B. $30 \mathrm{~mm}$; C. $10 \mathrm{~mm}$.

The last group of endolithic animals found during the present study, the sipunculids, was rare, represented by eight specimens belonging to three species, a number even lower than that obtained by Young (1986) on the northeastern coast of the country. Davies and Hutchings (1983) reported that this group only settled on the substrate after it reached an age of two or three years; since the corals collected for the present study were all small and, therefore, young, it is possible that the group becomes more numerous in larger colonies. Rice (1976) and Rice and Macintyre (1982) studied the boring activity of the group and concluded that it consists in both: secretion of acid solution by epidermal glands, and mechanical abrasion by epidermic plates. Curiously, although contemporary sipunculids are not among the most destructive coral-boring animals (Risk and Macgeachy, 1978; Highsmith et al., 1983), they are the most ancient group of rock boring animals known from the fossil record (James et al., 1977).

Throughout the present study, no boring sponges were detected. This was somewhat unexpected as sponges have been reported to be the most prevalent of all coral borers (Hein and Risk, 1975; MacGeachy and Stearn, 1976), and clionids, the most effective of the boring sponges, have been reported on the coast of the State of São Paulo (Hajdu, 1997).
The barnacle Ceratoconcha floridana was first observed in Brazil by Young and Christoffersen (1986), from the northeastern coast until the State of Rio de Janeiro. At that time, the authors forecasted that it had the same distribution as its host, and so it could also be present in the State of São Paulo, what has now been confirmed. The animal is a filter-feeder with strong connection with the corals (Fig. 2B, C), immediately dying should the polyps around it die (Young, personal communication).

It is also the first report for cryptochiridean crabs, the "gall-crabs", in the State of São Paulo. They were easily recognised by their half-moon shaped holes, with lateral grooves to accommodate the legs of the animals (Fig. 2B, C). Probably these animals are not borers, instead, their larvae settle in the space between two polyps and mould the walls of their cavities as the corals grow (Scotto and Gore, 1981). Although cryptochiridean crabs are considered as filter-feeders, there is some doubt in regard to their ability to feed on corals mucus and tissues as well (Kropp, 1986); in the present study, coral tissues around cryptochiridean openings were not damaged.

The two species of fishes observed had never before been officially registered in waters of São Paulo, although Emblemariopsis signifera has commonly been seen in coral heads in all the 
islands of the northern coast of the state (Nogueira, personal observation). It is a small species, about 5 $\mathrm{cm}$ in length, which lives in elliptical holes, probably made by L. bisulcata; the walls of these cavities were totally covered by eggs and the fishes never move far from their holes. The only individual of the other species, Chriolepis vespa, was very short, probably a juvenile.

Among copepods, harpacticoids were the most diverse and representative group, with numerous species whose body shapes reflect adaptations (Hicks and Coull, 1983) to all microenvironments possible in a coral head. Other group of copepods common in M. hispida, the Siphonostomatoida, is parasitic on cnidarians and other sessile marine invertebrates (Ho, 1991; Humes, 1991), sucking their internal fluids by means of the fused mouthparts.

The pantopods observed probably fed on the animals incrusted at the underside of the corals, but they were rare. In the only study dealing with corals and associated fauna in which pantopods were mentioned (McCloskey, 1970), two genus were observed: Anoplodactylus and Tanystylum, both of them also identified here.

Although other papers frequently cited the decapods as the most numerous group on hard substrates (Gore et al., 1978; Tsuchyia et al., 1989), with many species adapted to live in close association with the corals (Gore et al., 1978; Glynn et al., 1985), no obligate symbionts other than cryptochiridean crabs were observed in the present study, but only few species, all poorly represented and also known from other habitats (Melo, 1996).

The ophiuroid Ophiactis savignyi is a cosmopolitan species, known in the Gulf of Thailand (Tsuchyia et al., 1989), northern Atlantic (McCloskey, 1970), and north-eastern Brazilian coast (Young, 1986) as a very common species associated with the corals. In São Paulo, $O$. savignyi was the dominant species at polychaete tubes (Nalesso et al., 1995) and sponges (Duarte and Nalesso, 1996). Although it has not been the dominant species in any of the corals analysed for the present study, it was one of the most frequent, having been collected in 16 coral heads.

It should be noted that most of the animals found in the fixative solution were also found in habitats other than corals, such as algal fields (Montouchet, 1979; Tararam and Wakabara, 1981; Wakabara et al. 1983; Tanaka, 2000), sponges (Duarte and Nalesso, 1996), polychaete tubes (Nalesso et al.,
1995), and bryozoans (Morgado, 1980). In corals, most of them were omnivorous, feeding on bacteria, detritus and coral mucus.

Ayal and Safriel (1982) proposed that the underside of the corals provided very effective protection for young and juvenile animals; the authors claimed that as these animals grew, they passed to adjacent areas, leaving space for new settlements. This coincided with the patterns observed in the present study, since high numbers of young specimens and ovigerous females were detected in all groups. It should, thus, be said that corals acted as a "nursery place" for most of the associated species.

The cluster analysis showed high heterogeneity among the corals studied, a fact that has also been noted in algae by Tanaka (2000). The fact was also corroborated by the $t$-tests performed, which showed no significant correlation between any of the metric parameters of the corals and the community descriptors. Therefore, this heterogeneity suggested that in the first stages of colonisation, as the corals collected for the present study were, the colonies were occupied randomly, but sooner or later they were fully colonised, and once they achieved a certain size (larger than those here treated) all bore a very rich fauna, similar between different coral heads, what was confirmed by field observations (Nogueira, personal observation). Besides, each coral head has particular characteristics, such as the exposition to light, circulation of water and amount of basal area exposed, which may also influence the associated community. As the corals grow older, the number of associates increases, because of the greater space available and also because the endolithic forms create galleries inside the calcareous framework, opening space for the settlement of new larvae (Kiene and Hutchings, 1992).

Tanaka (2000) studied the fauna living in Sargassum stenophyllum and found that amphipods were the most representative group, followed by polychaetes, gastropods and isopods. As that study was focused on the macrofauna, the author sorted the material with a $0.5 \mathrm{~mm}$ sieve, and therefore it was not possible to evaluate the role of copepods on those habitats.

In the present paper, amphipods were also very representative, having been the third group in the number of specimens, after copepods and isopods. An initial survey on the algae-associated fauna at Alcatrazes Island (Nogueira, unpublished), in which the methodology adopted was the same as 
in the present study (e. g. all animals, independent of size, were sorted under stereomicroscope) showed that communities living in corals and algae were very similar and further studies could reveal interesting similarities and differences between these environments.

Finally, not all the animals living in the corals were parasitic or comensals. Instead, several associates benefit the hosts by preying upon the larvae of boring animals, as mentioned before for the incrusting community, by removing detritus and coral mucus, and even by attacking potential predators of the corals (Glynn, 1983; deVantier et al., 1986).

\section{RESUMO}

Colônias de Mussismilia hispida foram coletadas em quatro ilhas do sudeste brasileiro e fixadas em formalina. Depois de medidos o volume e as areas vivas e da base de cada coral, os animais encontrados sobre, dentro e sob as colônias foram triados, resultando em 9657 espécimes, pertencentes a cerca de 130 espécies. As bases das colônias encontravam-se ocupadas por bivalves e colônias de esponjas, briozoários e ascídias; na superfície viva, cirripédios e "caranguejos-galha" se fizeram presentes; a fauna endolítica incluiu poliquetas, bivalves e sipúnculos. Crustáceos vágeis, tais como copépodes, isópodes, anfípodes, tanaidáceos e ostrácodes responderam pela maioria dos animais encontrados. De maneira geral, podese dizer que os corais neste ambientes: (1) atuam como um local protegido para a reprodução das espécies associadas; (2) fornecem abrigo a muitas espécies também encontradas em outros ambientes; (3) sustentam uma comunidade que se alimenta principalmente de bactérias, detritos e do muco dos corais; (4) são inicialmente colonizados ao acaso.

\section{ACKNOWLEDGEMENTS}

I would like to express my gratitude to $\mathrm{CNPq}$, for the financial support; to Erika Schlenz for the supervision during my Master of Sciences course, which rendered the present work; to Cecília Amaral for the valuable suggestions; to André Eterovic for the help on statistics; and to the specialists who identified, or helped on the identification of the animals collected: Álvaro E. Migotto (hydroids), Ana Maria P. Vanin (isopods), Antônio Sérgio F. Ditadi (sea urchins and sipunculids), Carlos E. F. da Rocha (copepods), Erika Schlenz (sea anemones), Francy M. F. Varoli (pantopods), Gustavo A. S. Melo (decapods), Luiz R. de Simone (molluscs), Luís Tommasi (ophiuroids), Paulo S. Young (barnacles), Setuko Matsunari (tanaids), and Yoko Wakabara (amphipods).

\section{REFERENCES}

Arvanitides, C. and Koukouras, A. (1994), Polychaete fauna associated with the coral Cladocora caespitosa (L.) in the eastern Mediterranean. Mém. Mus. Nat. Hist. Natur. Sér. A (zool.), 162, 347-353.

Ayal, Y. and Safriel, U. N. (1982), Species diversity of the coral reef - a note on the role of predation and adjacent habitats. Bull. Mar. Sci., 32 : (3), 787-790.

Buss, L. W. and Jackson, J. B. C. (1979), Competitive networks: nontransitive competitive relationships in cryptic coral reef environments. Am. Nat., 113 : (2), 223-234.

Choi, D. R. (1984), Ecological sucession on reef cavitydwellers (coelobites) in coral rubble. Bull. Mar. Sci., 35 : (1), 72-79.

Chughtai, I. and Knight-Jones, E. W. (1988), Burrowing into limestone by sabellid polychaetes. Zool. Scrip., 17, 231-238.

Coles, S. L. (1980), Species diversity of decapods associated with living and dead reef coral Pocillopora meandrina. Mar. Ecol. Prog. Ser., 2, 281-291.

Davies, P. J. and Hutchings, P. A. (1983), Initial colonization, erosion and accretion on coral substrate (experimental results, Lizard Island, Great Barrier Reef). Coral Reefs, 2, 27-35.

DeVantier, L. M.; Reichelt, R. E. and Bradbury, R. H. (1986), Does Spirobranchus giganteus protect host Porites from predation by Acanthaster planci: predator pressure as a mechanism of coevolution? Mar. ecol. Prog. Ser., 32, 307-310.

Duarte, L. F. L. and Nalesso, R. C. (1996), The sponge Zygomicale parishii (Bowerbank) and its endobiotic fauna. Estuar. Coast. Shelf. Sci., 42, 139-151.

Fauchald, K. and Jumars, P. A. (1979), The diet of worms: a study of polychaete feeding guilds. Oceanogr. Mar. Biol. Ann. Rev., 17, 193-284.

Glynn, P. W. (1983), Increased survivorship in corals harbouring crustacean symbints. Mar. Biol. Let., 4, 105-111.

Glynn, P. W.; Perez, M. and Gilchrist, S. L. (1985), Lipid decline in stressed corals and their crustacean symbionts. Biol. Bull., 168, 276-284. 
Gore, R. H.; Scotto, L. E. and Becker, L. J. (1978), Community composition, stability, and trophic partitioning in decapod crustaceans inhabiting some subtropical sabelariid worm reefs. Bull. Mar. Sci., 28 : (2), 221-248.

Hadfield, M. G. (1976), Molluscs associated with living tropical corals. Micronesica, 12 : (1), 133-148.

Hajdu, E. (1997), Lista de Porífera marinhos registrados para o litoral do Estado de São Paulo. In: Biodiversidade de Estado de São Paulo - BIOTA/SP. Campinas.

Hein, F. J. and Risk, M. J. (1975), Bioerosion of coral heads: inner patch reefs, Florida Reef Tract. Bull. Mar. Sci., 25 : (1), 133-138.

Hicks, G. R. F. and Coull, B. C. (1983), The ecology of marine meiobenthic harpacticoid copepods. Oceanogr. Mar. Biol. Ann. Rev., 21, 67-175.

Highsmith, R. C. (1980), Geographic patterns of coral bioerosion: a productivity hypothesis. J. Exp. Mar. Biol. Ecol., 46, 177-196.

Highsmith, R. C.; Lueptown, R. L. and Schönberg, S. C. (1983), Growth and bioerosion of three massive corals on the Belize Barrier Reef. Mar. Ecol. Prog. Ser., 13, 261-271.

Ho, J. S. (1991), Phylogeny of Poecilostomatoida: a major order of symbiotic copepods. Bull. Plankton. Soc. Japan, Spec., 1991, 25-48.

Humes, A. G. (1991), Copepoda associated with the scleractinian coral genus Montipora in the IndoPacific. Proc. Biol. Soc. Wash., 104 : (1), 101-137.

Hutchings, P. A. (1986), Biological destruction of coral reefs. Coral Reefs, 4, 239-252.

Jackson, J. B. C. and Winston, J. E. (1982), Ecology of cryptic coral reef communities. I Distribution and abundance of major groups of encrusting organisms. J. Exp. Mar. Biol. Ecol., 57, 135-147.

James, N. P.; Kobluk, D. R. and Pemberton, S. G. (1977), The oldest macroborers: lower Cambrian of Labrador. Science, 197, 980-983.

Kiene, W. E. and Hutchings, P. A. (1992), Long-term bioerosion of experimental coral substrates from Lizard Island, Great Barrier Reef. Proc. VII ${ }^{\text {th }}$ Int. Coral Reef Symp., Guam, 1, 397-403.

Kohn, A. J. and Lloyd, M. (1973), Polychaetes of truncated reef limestones on eastern Indian Ocean coral reefs: diversity, abundance and taxonomy. Int. Rev. ges. Hydrobiol., 58 : (3), 369-399.

Kropp, R. K. (1986), Feeding biology and mouthpart morphology of three species of coral gall crabs (Decapoda: Cryptochiridae). J. Crust. Biol., 6 : (3), 377-384.

MacGeachy, J. K. and Stearn, C. W. (1976), Boring by macro-organisms in the coral Montastrea annularis on Barbados reefs. Int. Rev. Ges. Hydrobiol., 61 : (6), 715-745.

Magurran, A. E. (1988), Ecological Diversity and its Measurement. Princeton University Press, New Jersey.
Martin, D. and Britayev, T. A. (1998), Symbiotic polychaetes: review of the known species. Oceanogr. Mar. Biol. Ann. Rev., 36, 217-240.

McCloskey, L. R. (1970), The dynamics of the community associated with a marine scleractinian coral. Int. Rev. Ges. Hydrobiol., 55 : (1), 13-81.

Melo, G. A. S. (1996), Manual de Identificação dos Brachyura (caranguejos e siris) do Litoral Brasileiro. São Paulo : Plêiade.

Montouchet, P. C. G. (1979), Sur la communauté des animaux vagiles associés à Sargassum cymosum C. Agardh, à Ubatuba, Etat de São Paulo, Brésil. Stud. Neotrop. Fauna Environ., 14, 33-64.

Moretzsohn, F. and Tsuchyia, M. (1992), Preliminary survey of the coral boring Bivalvia fauna of Okinawa, southern Japan. Proc. VII ${ }^{\text {th }}$ Int. Coral Reef Symp., Guam, 1, 404-412.

Morgado, E. H. (1980), A endofauna de Schizoporella unicornis (Johnston, 1847) (Bryozoa) no litoral norte do Estado de São Paulo. MSc thesis, Universidade Estadual de Campinas, Campinas, Brazil.

Morton, B. S. (1983), Coral-associated bivalves of the Indo-Pacific. In: Russell-Hunter, W. D. (ed.). The Mollusca. v. 6 - Ecology. Academic Press, London. pp 139-224.

Nalesso, R. C.; Duarte, L. F. L.; Pierozzi Jr., I. and Enumo, E. F. (1995), Tube epifauna of the polychaete Phyllochaetopterus socialis Claparède. Estuar. Coast. Shelf Sci., 41, 91-100.

Nogueira, J. M. M. (2000), Anelídeos poliquetas associados ao coral Mussismilia hispida (Verrill, 1868) em ilhas do litoral do Estado de São Paulo. Phyllodocida, Amphinomida, Eunicida, Spionida, Terebellida e Sabellida. PhD thesis, Universidade de São Paulo, São Paulo, Brazil.

Nogueira, J. M. M. (2002), Asclerocheilus tropicus Blake, 1981 (Polychaeta, Scalibregmatidae): redescription based on Brazilian specimens. Proc. Biol. Soc. Wash., 115 : (2), 323-332.

Nogueira, J. M. M. and Amaral, A. C. Z. (2000), Amphicorina schlenzae, a small sabellid (Polychaeta, Sabellidae) associated with a stony coral on the coast of São Paulo state, Brazil. Bull. Mar. Sci., 67 : (1): 617-623.

Nogueira, J. M. M. and Amaral, A. C. Z. (2001), New terebellids (Polychaeta, Terebellidae) living in colonies of a stony coral in the state of São Paulo, Brazil. Proc. Biol. Soc. Wash., 114 : (1), 285-296.

Nogueira, J. M. M. and ten Hove, H. A. (2000), On a new species of Salmacina Claparède, 1870 (Polychaeta: Serpulidae) from São Paulo State, Brazil. Beaufortia, 50 : (8), 151-162.

Nogueira, J. M. M. and Knight-Jones, P. (2002), A new species of Pseudobranchiomma Jones (Polychaeta: Sabellidae) found amongst Brazilian coral, with a redescription of $P$. punctata (Treadwell, 1906) from Hawaii. J. Nat. Hist., 36 : (14), 1661-1670. 
Nogueira, J. M. M. and Rizzo, A. E. (2001), A new species of Branchiomaldane (Polychaeta: Arenicolidae) from the state of São Paulo, southeastern Brazil. J. Mar. Biol. Ass. U.K., 81, 415-421.

Nogueira, J. M. M. and San Martín, G. (2002), Species of Syllis Savigny in Lamarck, 1818 (Polychaeta: Syllidae) living in corals in the State of São Paulo, southeastern Brazil. Beaufortia, 52 : (7), 57-93.

Nogueira, J. M. M.; San Martín, G. and Amaral, A. C. Z. (2001), Description of five new species of Exogoninae Rioja, 1925 (Polychaeta: Syllidae) aasociated with the stony coral Mussismilia hispida (Verrill, 1868) in São Paulo State, Brazil. J. Nat. Hist., 35 : (12), 1773-1794.

Nogueira, J. M. M.; Steiner, T. M. and Amaral, A. C. Z. (2001), Description of two new species of Eunice Cuvier, 1817 (Polychaeta, Eunicidae) from islands off the coast of São Paulo state, Brazil. Sci. Mar., 65 : (1), 47-57.

Patton, W. K. (1966), Decapod crustacea commensal with Queensland branching corals. Crustaceana, 10 : (3), 271-295.

Rice, M. E. (1976), Sipunculans associated with coral communities. Micronesica, 12 : (1), 119-132.

Rice, M. E. and Macintyre, I. G. (1982), Distribution of Sipuncula in the coral reef community, Carrie Bow Cay, Belize. In: The Atlantic Barrier Reef Ecosystem at Carrie Bow Cay, Belize, 1: Structure and Communities, eds. K. Rützler and I.G. Macintyre. Smithson. Contrib. Mar. Sci., 12, 311-320.

Rios, E. C. (1985), Seashells of Brazil. Fundação Universidade do Rio Grande, Museu Oceanográfico, Rio Grande.

Risk, M. J. and Macgeachy, J. K. (1978), Aspects of bioerosion of modern Caribbean reefs. Rev. Biol. Trop., 26 : (1), 85-105.

Rützler, K. (1975), The role of sponges in bioerosion. Oecologia, 19, 203-216.

Scotto, L. E. and Gore, R. H. (1981), Laboratory cultured zoel stages of the coral gall-forming crab Troglocarcinus corallicola Verrill, 1908 (Brachyura: Hapalocarcinidae) and its familial position. J. Crust. Biol., 1 : (4), 486-505.

Simone, L. R. L. (1995), Rissoella ornata, a new species of Rissoellidae (Mollusca: Gastropoda: Rissoelloidea) from the south-eastern coast of Brazil. Proc. Biol. Soc. Wash., 108 : (4), 560-567.

Steiner, T. M.; Nogueira, J. M. M. and Amaral, A. C. Z. (2002), Eunice rubra Grube (Annelida, Polychaeta, Eunicidae), a redescription based on the holotype and Brazilian specimens. Rev. Bras. Zool., 19 : (Supl. 1), 243-259.

Tanaka, M. O. (2000), Distribuição especial e dispersão entre manchas da macrofauna associada ̀̀ alga parda Sargassum stenophyllum (Mertens) Martius. PhD thesis, Universidade Estadual de Campinas, Campinas, Brazil.
Tararam, A. S. and Wakabara, Y. (1981), The mobile fauna - especially Gammaridae - of Sargassum cymosum. Mar. Ecol. Prog. Ser., 5, 157-163.

Tsuchyia, M.; Nakasome, Y. and Nishihira, M. (1989), Species composition of small animals associated with the coral Pocillopora damicornis at Sichang Islands, the Gulf of Thailand: size effect of coral colony. Galaxea, 8, 257-269.

Wakabara, Y.; Tararam, A. S. and Takeda, A. M. (1983), Comparative study of the amphipod fauna living on Sargassum of two Itanhaém shores, Brazil. J. Crust. Biol., 3 : (4), 602-607.

Yonge, C. M. (1955), Adaptation to rock boring in Botula and Lithophaga (Lamellibranchia, Mytilidae) with a discussion on the evolution of this habitat. Quart. J. Mic. Sci., 96, 383-410.

Young, P. S. (1986), Análise qualitativa e quantitativa da fauna associada a corais hermatípicos (Coelenterata: Scleractinia) nos recifes de João Pessoa, PB. Rev. Bras. Zool., 3 : (1), 99-126.

Young, P. S. and Christoffersen, M. L. (1984), Recent coral barnacles of the genus Ceratoconcha (Cirripedia: Pirgomatidae) from northeast Brazil. Bull. Mar. Sci., 35 : (2), 239-252.

Received: November 21, 2000; Revised: October 21, 2002; Accepted: March 05, 2003. 